\title{
Wollemia nobilis, a new living Australian genus and species in the Araucariaceae
}

\author{
W.G. Jones, K.D. Hill and J.M. Allen
}

\begin{abstract}
Jones, W.G. ${ }^{1}$, Hill, K.D. ${ }^{2}$ and Allen, J.M. ${ }^{3}$ ("New South Wales National Parks and Wildlife Service, PO Box 43, Blackheath, NSW, Australia 2785, ${ }^{2}$ National Herbarium of New South Wales, Royal Botanic Gardens, Sydney, NSW, Australia 2000, ${ }^{3} \mathrm{Cl}-12$ Oku St, Island Bay, Wellington, New Zealand) 1995. Wollemia nobilis, a new living Australian genus and species in the Araucariaceae. Telopea 6(2-3): 173-176. A recently discovered plant from Wollemi National Park in New South Wales is described as Wollemia nobilis, a new species in a new genus in the family Araucariaceae.
\end{abstract}

\section{Introduction}

A stand of large trees has recently been discovered in a remote part of the Wollemi Wilderness. The finder (David Noble) realised that it was unusual, and showed a fragment to one of us (WJ). It was subsequently recognised as a distinctive new taxon, and is here described as a new species and genus in the Araucariaceae.

Wollemia W.G. Jones, K.D. Hill \& J.M. Allen, gen. nov.

Agathi affinis, sed characteribus sequentibus differt: folia trimorpha, helicalis, decurrentia; strobili terminales; bracteae squamaeque perfecte connatae spiniferaeque; semina ala cincta.

Type species: Wollemia nobilis W.G. Jones, K.D. Hill \& J.M. Allen

Monoecious glabrous trees. Leaves trimorphic, closely spaced, broad-based, decurrent, helically arranged on orthotropic branches, distichous or tetrastichous on plagiotropic branches, with numerous subparallel longitudinal veins and no conspicuous midrib, hypostomatic or amphistomatic. Male strobili terminal on firstorder plagiotropic branches, cylindrical, male sporophylls helically arranged, with short pedicels and somewhat thickened valvate apices. Female strobili terminal on first-order plagiotropic branches, spiny; bract and ovuliferous scale fully fused, with two vascular traces to the bract and three inverted traces to the seed, bract-scales winged, helically arranged, bearing a single inverted ovule adaxially and centrally. Bract-scales shedding at maturity to leave the persistent thick central axis. Seeds with a single circumferential wing, free from bract-scale. Germination epigeal. Cotyledons two, oblong, subsessile, with fine subparallel longitudinal veins.

Notes: This taxon is clearly placed within the Araucariaceae by the broad leaves with several parallel veins and no distinct midvein, the microsporophylls each with 4-9 pendulous microsporangia, the wingless pollen, and the large female strobili with numerous fully fused bract-scale complexes, each with a single inverted ovule that develops into a dry winged seed. It differs from Araucaria in the trimorphic, generally obtuse or rounded leaves, the fully fused bract and ovuliferous scale, with no evident vestigial scale tip ('ligule'), and the winged seed that is shed separately from the scale. It differs from Agathis in the trimorphic, closely crowded, sessile, decurrent leaves, the amphistomatic, tetrastichous adult leaves, the attenuate bractscales, and the circumferentially winged seeds. Distinguishing characters of Wollemia 
not shared with either Araucaria or Agathis are the spongy, nodular bark that sheds its outer surface in thin papery scales, and the terminal placement of male and female strobili on first-order branches. Molecular, morphological and anatomical studies in hand will further address the placement of Wollemia and relationships with fossil and extant taxa within the Araucariaceae.

Wollemia is a monotypic genus, with a single rare species known.

Wollemia nobilis W.G. Jones, K.D. Hill \& J.M. Allen, sp. nov.

Arbor elata cortice nodosa spongiosaque; rami inferi foliis distichis, linearibus, obtusis, hypostomaticis; rami superi foliis tetrastichis, oblongis, obtusis, amphistomaticis; strobili masculi magni, 7-11 cm longi, 13-19 $\mathrm{mm}$ diametro.

Type: New South Wales: Central Tablelands: Wollemi National Park, W.G. Jones NSW 362731, 17 Nov 1994 (holo NSW; iso BM, BRI, CANB, E, HO, K, L, MEL, MO, NY, P).

Monoecious trees to $40 \mathrm{~m}$ tall, frequently coppicing from base; trunks to $1.2 \mathrm{~m}$ diam.; crown slender, columnar, broadest at about $1 / 3$ of total height. Bark peeling in thin, fragile, equidimensional dark red-brown scales on younger stems, becoming densely covered with soft and spongy nodules or tubercles to $10 \mathrm{~mm}$ diam. and 15 $\mathrm{mm}$ long on older trunks, forming a layer to $20 \mathrm{~mm}$ deep. Foliage trimorphic. Orthotropic shoots with helical phyllotaxis and acute, pungent, keeled, decurrent, narrowly triangular leaves 3-10 mm long, 2-4 $\mathrm{mm}$ wide at base. Juvenile and lower canopy plagiotropic shoots horizontal, leaves opposite or subopposite, distichous and twisted to present adaxial surfaces uppermost, linear to narrowly triangular, chartaceous, rounded or obtuse, hypostomatic, deep green above, glaucous below, broad-based and decurrent, with 6-10 parallel veins and 4-6 parallel resin canals; repetitive growth units commencing with short scale-like leaves to $3 \mathrm{~mm}$ long, leaves increasing to $20-80 \mathrm{~mm}$ long, 2-5 mm wide. Adult upper canopy plagiotropic shoots initially near-vertical, becoming horizontal and later pendulous, leaves opposite or subopposite,
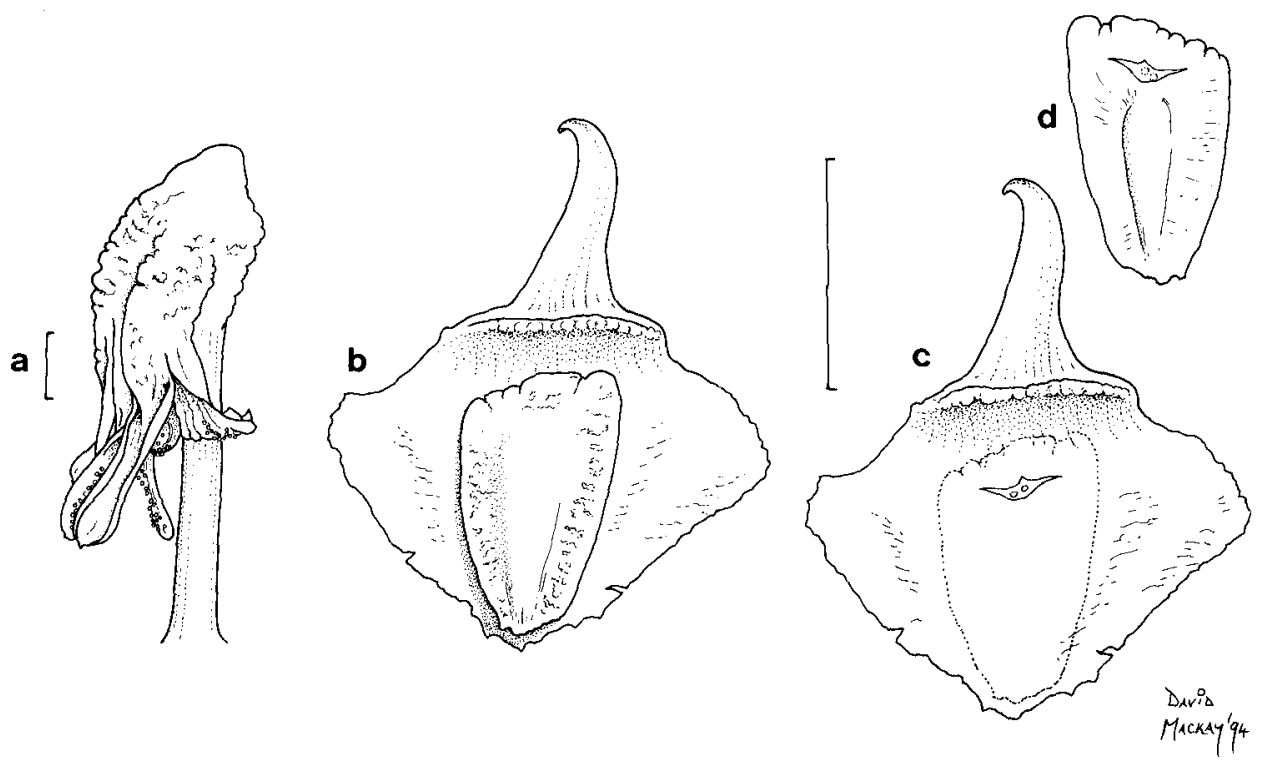

Fig. 1. Wollemia nobilis, a microsporophyll, $\mathbf{b}$ female bract-scale complex with attached seed, $\mathbf{c}$ female bract-scale complex with seed detached, $\mathbf{d}$ seed. Scale bar, $\mathbf{a}=1 \mathrm{~mm}, \mathbf{b}, \mathbf{c}, \mathbf{d}=5 \mathrm{~mm}$. 


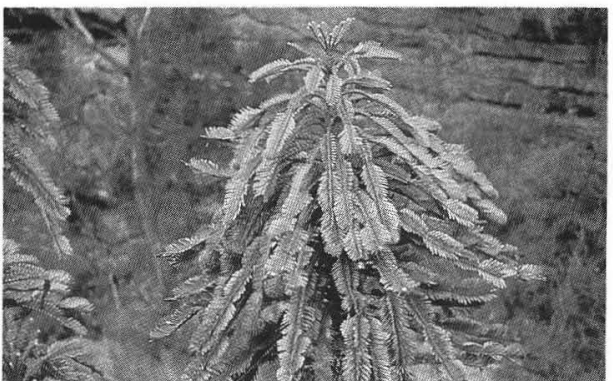

a

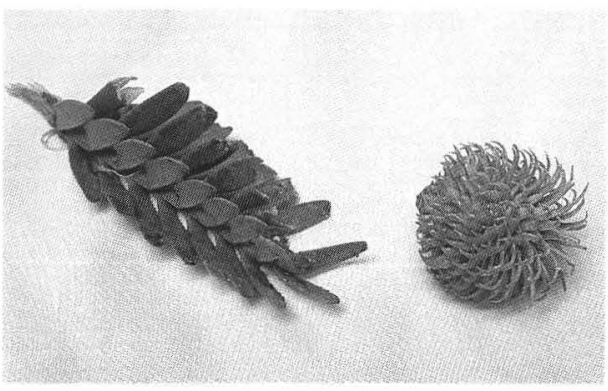

c

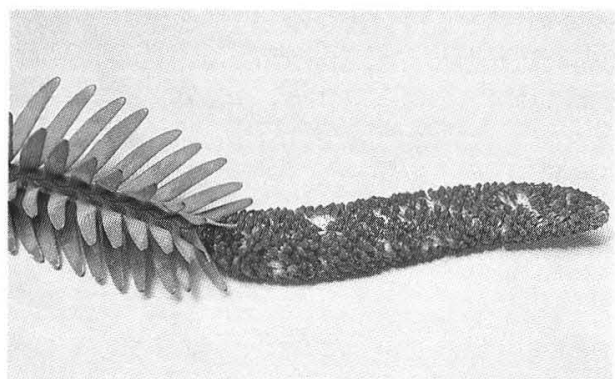

b

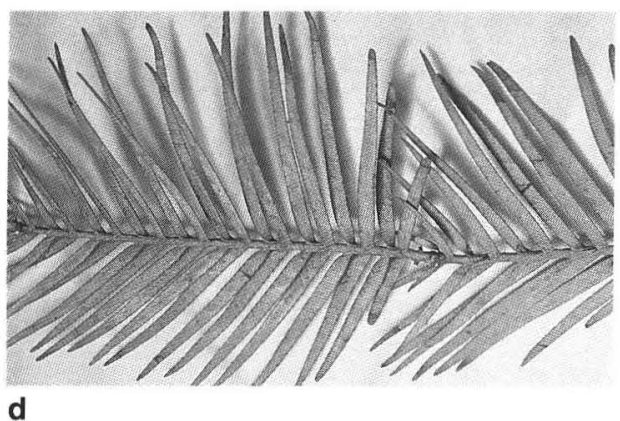

Fig. 2. Wollemia nobilis, a habit, b male strobilus (10 cm long), c female strobilus (7.0 cm diam.), d juvenile foliage (longest leaves $65 \mathrm{~mm}$ long).

tetrastichous and twisted to present adaxial surfaces uppermost, narrowly oblong, coriaceous, rounded, dull light to mid green, unequally amphistomatic, broad-based and decurrent, with 9-14 parallel veins and 6-8 parallel resin canals; repetitive growth units commencing with short scale-like leaves to $3 \mathrm{~mm}$ long, leaves increasing to $10-40 \mathrm{~mm}$ long, 4-8 $\mathrm{mm}$ wide. Male strobili terminal on first-order leafy plagiotropic shoots, to $109 \mathrm{~mm}$ long, $19 \mathrm{~mm}$ diam., subtended by c. 8 helically arranged broadly triangular to semicircular bracts $3-5 \mathrm{~mm}$ long, $3-5 \mathrm{~mm}$ wide. Microsporophylls numerous (more than 500), helically arranged, dark red-brown, peltate, with a raised, angular termination, with 4-9 elongate, pendulous microsporangia. Pollen ovoid, inaperturate, granular, unwinged. Female strobili terminal on first-order leafy plagiotropic shoots, usually borne on ascending branches above male strobili, globular to broadly ellipsoidal, mid green, becoming brown and shedding individual bractscales at maturity, to $125 \mathrm{~mm}$ long, $100 \mathrm{~mm}$ diam. Bract-scales numerous (more than 300), flattened, laterally winged, $12-17 \mathrm{~mm}$ long, $14-22 \mathrm{~mm}$ wide, $3-5 \mathrm{~mm}$ thick, with a narrowly triangular apical extension 6-12 $\mathrm{mm}$ long, 2-4 $\mathrm{mm}$ wide at base, bearing a single inverted ovule adaxially and centrally. Scales wholly fused with and indistinguishable from bracts. Seeds circumferentially winged, pale brown, 7-11 $\mathrm{mm}$ long, 5-7 $\mathrm{mm}$ wide, 6-9 $\mathrm{mm}$ wide including wing. Germination epigeal, cotyledons 2, oblong, 20-30 mm long, 4-6 mm wide, with c. 8 parallel veins and no discernable midrib. Figs. 1, 2.

Notes: Leaves on adult plagiotropic shoots are opposite or subopposite in insertion, but twisted to present four ranks, with two ranks at about $150-175^{\circ}$ and the other two ranks lying between the first two at about 50-90 . This arrangement may be interpreted as a double helical condition, in keeping with the helical arrangement of the other vegetative and reproductive structures. Leaves on juvenile plagiotropic shoots are also opposite or subopposite, but distichously arranged. This again may be interpreted as a double helix. Strobili are terminal on first-order branches, but the 
growth and branching pattern of the shoots following coning is still unclear. In most cases, it appears that the entire shoot is then shed at the orthotropic axis. Subsidiary branches in older trees develop from epicormic shoots that develop from the trunk after initial lateral branches have fallen.

Distribution: Known from a single population of about 20 mature trees and a similar number of juvenile plants, occurring in a remote part of the Wollemi National Park, within $200 \mathrm{~km}$ north-west of Sydney in the Central Tablelands of New South Wales. The precise locality has been withheld for conservation reasons.

Ecology: Trees are emergent above warm temperate rainforest dominated by Ceratopetalum apetalum D. Don ('Coachwood') and Doryphora sassafras Endl. ('Sassafras'), in a deep sheltered gorge surrounded by sandstone cliffs of the Triassic Narrabeen Group. Tall eucalypt woodland dominated by Eucalyptus piperita Sm. is adjacent, giving way to dry open woodland up-slope. Soil is sandstone-derived boulder alluvium, with high organic matter, some shale component and a substantial basalt wash from higher reaches of small tributary canyons. The local microclimate is wet, with a permanent creek and an understorey dominated by ferns (including Dicksonia antarctica, Cyathea australis, Sticherus flabellatus, Adiantum diaphanum, Doodia aspera and Blechnum nudum). Although small, the population shows a range of size classes, copious seed production and active seedling regeneration.

Conservation status: 2ECi. Although within a national park, the extremely small population and the fragile habitat suggest that this species should be regarded as endangered and inadequately conserved.

Etymology: The generic epithet recalls the Wollemi National Park, where this plant was found. The name is originally from the Aboriginal word wollumii, 'look around you' or 'watch your step'. The specific epithet honours David Noble of the New South Wales National Parks and Wildlife Service, a contemporary explorer of the remote parts of the Blue Mountains, who first discovered this plant.

Selected specimens: New South Wales: Central Tablelands: Wollemi National Park, Jones, Allen $\mathcal{E}$ Turton, 18 Nov 1994 (NSW 362732, BM, BRI, CANB, E, HO, K, L, MEL, MO, NY, P), Jones, 17 Nov 1994 (NSW).

\section{Acknowledgements}

We thank David Mackay for the botanical drawings, Tony Rodd and Jaime Plaza for photographs, and Peter Wilson for assistance with Latin diagnoses. Chris Page and Chris Quinn commented helpfully and encouragingly on the manuscript.

Manuscript received 23 December 1994 Manuscript accepted 30 March 1995 